\title{
Past, Present and Future of Indravati River Capture : A Geomorphological Investigation
}

\author{
Sandeep Vansutre*, S. D. Deshmukh** and K. R. Hari*** \\ *Kushabhau Thakre University of Journalism \& Mass Communication, Raipur (C.G.) \\ **Department of Geology, Govt. V.Y.T. PG Autonomous College, Durg(C.G.) \\ ***S.O.S. in Geology and W.R.M., Pt. R.S. Shukla University, Raipur (C.G.)
}

\begin{abstract}
Indravati "The lifeline of Bastar" is changing its course, in style and degree in a very short span of time which has invited attention of geo-scientists and policy makers to avoid any expected unpleasant circumstances. Here we have investigated the drainage rearrangement of Indravati river water, where, earlier, Jaura Nala( which used to flow northwards) connecting Kolab river and Indravati river acting as a feeder for Indravati, now flowing southward and draining the water of Indravati, has become a matter of serious concern for the sediment budgets and biotic distributions in the surroundings. Due to the stated changes, the likely hydro morphological impacts have also been discussed along with the possible measures to be adopted to avoid any disparity in future.

A serious multidisciplinary probe into the possible causes ,the natural factors and human intervention, is warranted, taking in to account the considerations of changing surface topography including evidences derived from satellite and topographic data, understanding of geomorphological and sedimentological observations and impact due to man made structures like dams on the upstream side in Odisha.
\end{abstract}

Keywords: River capture, Indravati river, Chhattisgarh.

\section{Location And Background Information}

Bastar District having an area of $4029.98 \mathrm{~km}^{2}$ is surrounded by Kondagaon,Sukma,Dantewada and Bijapur Districts of Chhattisgarh and Odisha State in the east. The district headquarter Jagdalpur is situated at a distance of approximately $300 \mathrm{~km}$. south of Raipur, which is the capital of Chhattisgarh state. Almost the entire northern part of Kondagaon and Narayanpur districts is in undulating forest plateau, about 2000 feet high. There are disconnected chains of hills. The extensive mass of hills known as Abujhmar, is situated to the west and southwest of Narayanpur and bounded by Indravati on the south. Abujhmar still remains the terra incognita of the state of Chhattisgarh. The altitude of Abujhmar region ranges from 2000 to 3160 feet above mean sea level. The maximum elevation on the Tulsidongri range in the eastern part of the district is 3928 feet. About $51 \%$ of the total geographic area of the district is covered by forests.

The major geological formations in the district are high-grade gneiss, granulite and charnockite complex (Bengpal group) of Archaen age. These are overlain by Bailadila Group of rocks comprising Banded Iron Formation. The Bailadila group of rocks are intruded by acid igneous rocks like granites/granitoids. Besides these main cratonic rocks formations, the intracratonic, volcano-sedimintary suite of rocks of Abujmar group and the sediments of Indravati Group are also found. Laterites are found as hill cappings.

The beauty of Bastar district lies in its natural forest area and various types of tribals. Of the total population more than $70 \%$ are tribals like Gonds, Abhuj Maria,Darda Maria, Bison Horn Maria ,Munia Doria ,Dhruva,Bhatra ,Halba etc.

\section{Indravati - 'The Lifeline Of Bastar'}

The Bastar district receives a normal rainfall of $1600 \mathrm{~mm}$ with $60-70$ rainy days and it has a tropical climatic condition. The largest and the most important river in Bastar district is the Indravati which has numerous tributaries, the largest being the Pamer Chinta . With a tortuous course, Indravati river flows across the southern limit of the district. The Indravati river rises from Rampur Thuamul in the Odisha state and flowing through the Bastar division for about $240 \mathrm{~km}$ and finally merges into the Godavari at Bhadrakali in Dantewada district. Owing to its rocky bed the river is not navigable except near its junction at Godavari. It forms the boundary between Maharashtra and Chhattisgarh states at some places. Most of the river course of Indravati is through dense forests of Bastar. The famous 'Chitrakoot' fall forms on Indravati River, it is located at about 40 $\mathrm{km}$ from Jagdalpur, it is also known to be 'the Niagara of Chhattisgarh'. The Indravati River is sometimes known as the "lifeline" of the Bastar District, which is known as one of the greenest districts in India. There is a famous wildlife sanctuary named Indravati National Park on its bank. Other important rivers of the district are the Sabri, the Tel, the Narangi, the Gudra, the Kotri, the Dantewara, the Dudh and the Mahanadi. 


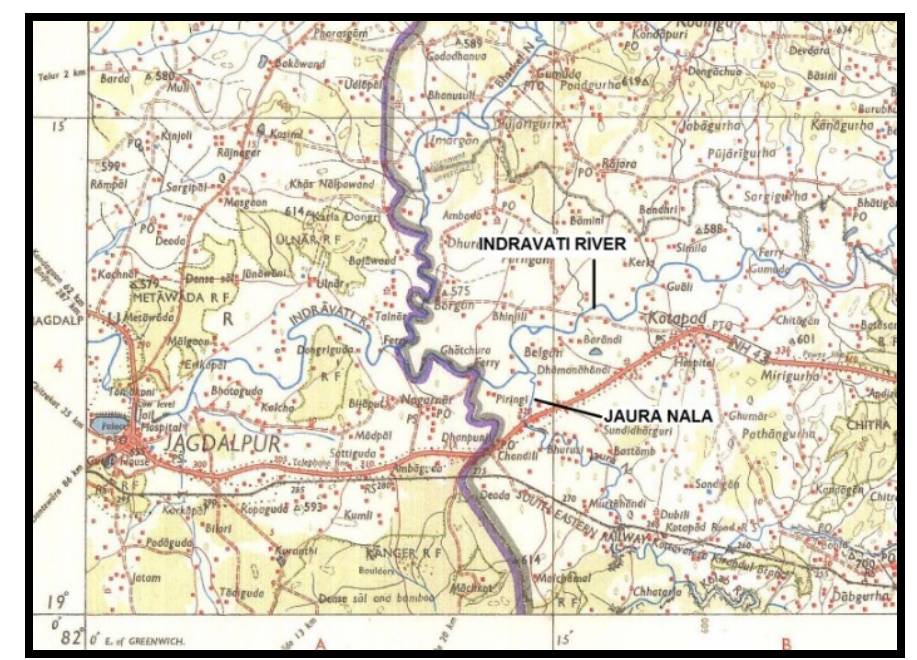

Fig. - 2(a) A part of toposheet no. 65- I(Scale 1:250,000) showing location of Jaura nala.

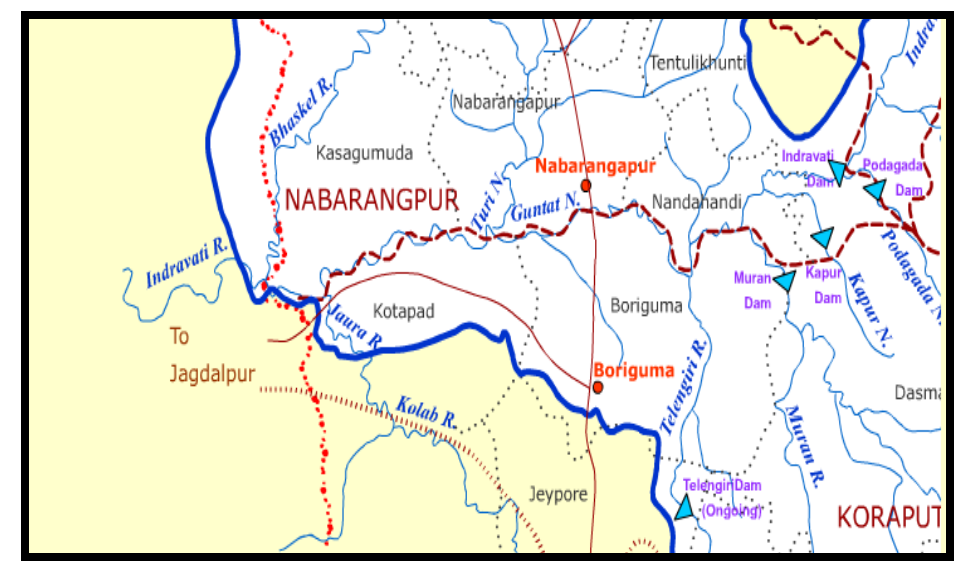

Fig. -2(b) A map showing location of Jaura nala joining Indravati river and Kolab river. (Source : Department of water resources, Odisha State)

\section{Present Status Of Indravati River}

Indravati, starting from Rampur of Kalahandi district, Odisha after entering in Bastar merges in Godawari river near village Timed of Bijapur district after crossing over $240 \mathrm{kms}$ long distance within Bastar territory. At present it is entering in Bastar dry and empty. Whatever water we are seeing in it is not its own water, but that of ancillary rivers and nalas like Bhaskel near Belgaon of Bakawand Tehsil of Bastar district. Thereafter, the water from rivers Narangi, Markanday, Shankini, Dankini, Mingechal etc has kept alive this died or better to say dried river Indravati.

\section{Dams On Indravati River}

Bodhghat Hydel Project is located on river Indravati near village Barsoor, about $100 \mathrm{Km}$ from Jagdalpur. The project was earlier cleared by Planning Commission in 1979. However, subsequently on enactment of Forest Conservation Act 1980, the Ministry of Environment \& Forest conveyed its inability for diversion of required 5704 hectares forest land. As a result all project activities were stopped.

After formation of the State of Chhattisgarh fresh efforts have been made by Govt. of Chhattisgarh \& CSEB to revive the project. The Ministry of Environment and Forest in February 2004 has accorded "In Principle Clearance" for diversion of required forest land for the project. Efforts are being made to revive the technoeconomic clearance from Central Electricity Authority and clearance from Ministry of Environment Forest.

The Bodhghat project involves the construction of a composite dam of a total length of $1,720 \mathrm{~m}$. The main dam would be $855 \mathrm{~m}$. long and $90 \mathrm{~m}$. high, with additional dams of $500 \mathrm{~m}$. and $365 \mathrm{~m}$. length on the left and right flanks respectively. The project would power four generating units of $125 \mathrm{MW}$ each. Conceived as a precursor to a series of dams (Kutru I and II, Nugur I and II, Bhopalpatnam and Inchampalli).

The series of dams on the river are planned such that the discharge level from the tail race of the upstream project would be nearly at the same level as the Full Reservoir Level of the next project downstream. 
Almost the entire length of the Indravati river would become one large reservoir, completely isolating the forests on either side of the river.

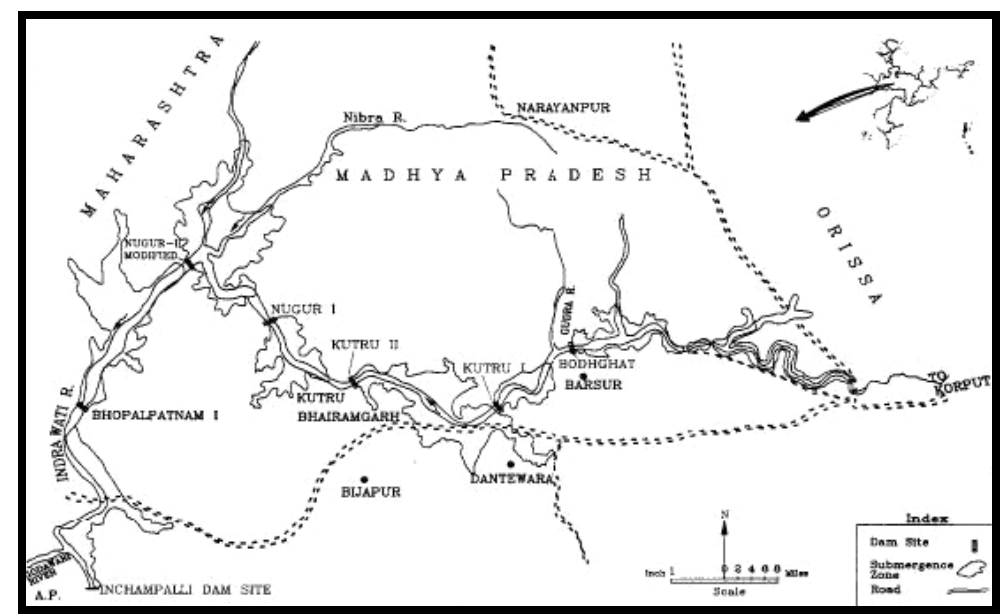

Figure- 3. Location of existing and proposed dams on Indravati river.

\section{Indravati River Capture: Course Of Events}

1. The Jaura Nala used to flow in northward direction, feeding the Indravati river and connecting Kolab river and Indravati river.

2. Inversion in the direction of flow of Jaura Nala took place around 1994-95 resulting in the draining of Indravati river water into Jaura Nala. Now the local people call the Jaura Nala as Ulta Jaura Nala (meaning Jaura Nala flowing in reverse direction).

3. The draining of Indravati river in Jaura nala resulted in two major consequences:-

A. Availability of less water downstream in the Indravati river.

B. Excess water and sediment load in Jaura Nala.

\section{Possible Cause For The Above Happening}

The natural flow of Indravati river has been obstructed due to dam construction, resulting in irregular flow of water in the river valley. This could have resulted in the decrease in sediment carrying capacity of Indravati river thus accumulating large amount of alluvium, which increased overall base level of river bed. The ultimate result was the inversion of the flow direction of Jaura Nala.

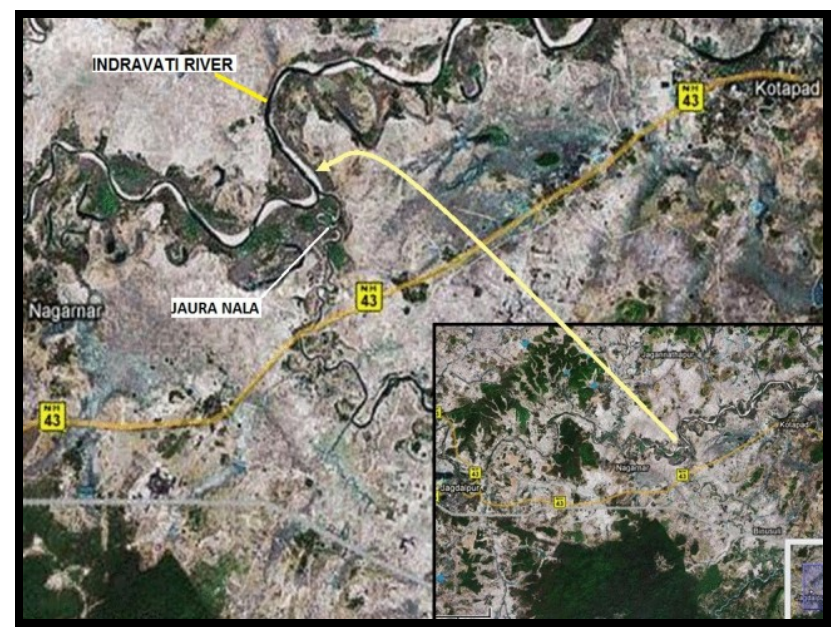

Fig. - 4. Google earth image showing the junction of Indravati river and Jaura Nala. 


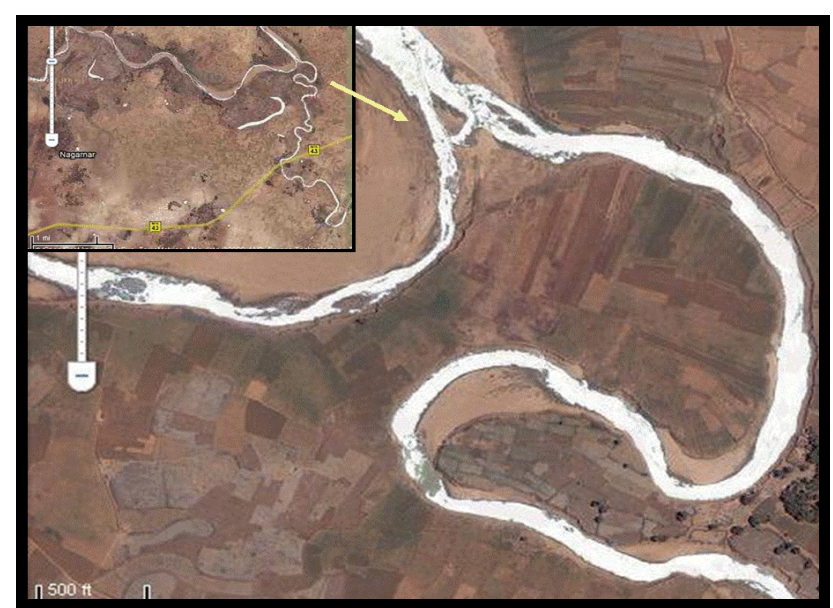

Fig. - 5 Google earth image showing closer view of the junction and meanders of Indravati river and Jaura Nala.

\section{Future Of The Indravati River}

As it can be seen in the Google earth images, if the present situation continues, the day is not very far in the future, when, the 'lifeline of Baster (Indravati river)' will be dead. Indravati recharges the groundwater in the region and helps in maintaining the ecological equilibrium in the region. It is the life source for the flora and fauna of Indravati National Park best known for its unique and miscellaneous wildlife and bird species including some of the rarest species such as Wild Buffalos and Hill Mynas. Prime habitat would be lost and wildlife movement would be completely ended if the river dries up. The wild buffalo, which prefers the cool habitats along the river, will soon vanish. The future of internationally recognized Chitrakot water fall is dark. This beautiful water fall will soon be dry point with rocks and sand.

\section{Steps Taken By The Government}

Chhattisgarh and Odisha states reached to consensus that Odisha will erect control structure over Jaura Nala in December 2003 during the meeting of Chief Engineers of both the states at Raipur.

The Superintending Engineer, Indravati Project division, holding Jaura Nala (Odisha) responsible for dried entry of Indravati River in Bastar, stated that this river is merging within its own ancillary nala, it is all due to geographical structure of merger area, the sum of rupees 340 lacs have been provided to Odisha for creating temporary dam system by logging sand bags at the mouth of Jaura Nala in order to confirm that the Indravati's own stream comes to Bastar, during non-monsoon season.

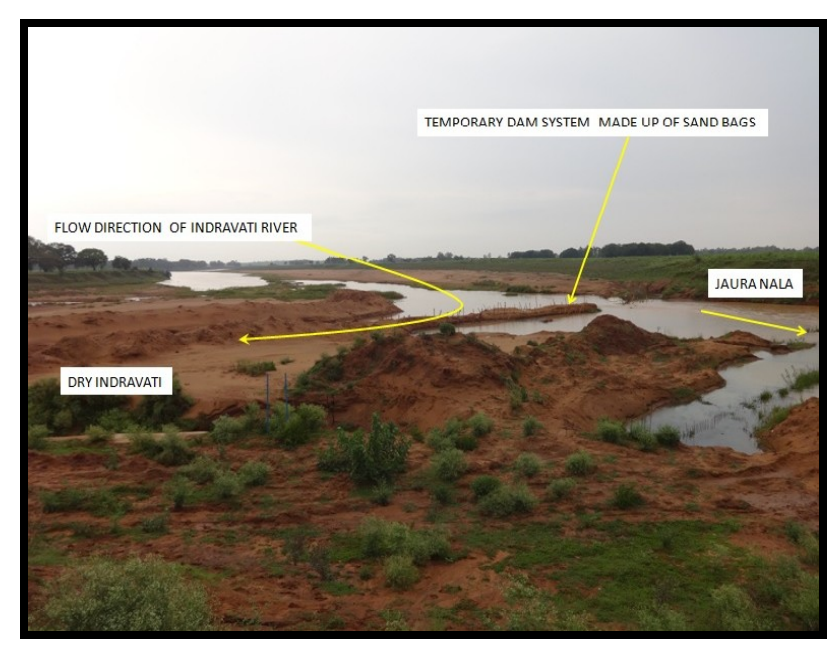

IX. Discussion And Conclusion

The rivers play a vital role in maintaining ecological balance at large and also in fine tune on the regional scale. The Jaura Nala meandering problem, leaving aside the possible reasons, has changed much in the region. As discussed earlier, there are some visible and some unforeseeable consequences due to this change of course. The reasons for delay in concrete action to mitigate the situation could be:

1. Involvement of two different states. 
2. A very unique and uncommon terrain, a part of which is not easily accessible.

3. Most of the area is covered by thick forest.

4. The area is industrially underdeveloped.

These are some of the observations, which contributed towards lack of proper attention. Here, leaving aside all political, administrative and regional prejudices, a special task force with an autonomous status of administrative and judicial powers must be constituted, which must also be complemented with a scientific executing team, which will implement the suggestions given by its counterpart in the benefit of the local habitat.

\section{Acknowledgement}

The authors are thankful to Shri Arvind Singh, Geologist, Chhattisgarh State Mineral Development Corporation, Raipur, Dr. Prabhat Diwan, Head, Department of Applied Geology, N.I.T. , Raipur , Shri Amitanshu Shekhar Jha, Assistant Professor, Department of Geology and Dr. Anil Kumar Mishra, Assistant Professor, Department of Geography, Govt. Kakatiya PG College, Jagdalpur, for the their help and fruitful discussions.

\section{References}

[1]. http://www.cseb.gov.in/cspgcl/powerproj/future\%20projects/future_proj_hydel.htm

[2]. http://www.dowrorissa.gov.in/BasinMaps/Indravati Basin.htm

[3]. http://eia.unu.edu/wiki/index.php/Assessed_impacts_of_the_proposed_Bodhghat_Hydroelectric_project.html

[4]. http://www.etdsonline.com Rajvanshi, A. (2007). Assessed impacts of the proposed Bodhghat Hydroelectric project

[5]. https://www.google.co.in/maps/search/google+earth+Jagdalpur+Indravati/

[6]. http://www.sanctuaryasia.com/component/content/article/119-campaigns-archive/682-bodhghat-damning-the-indravati-.html 